\title{
Mistrust and meddling unsettles US science agency
}

\section{National Science Foundation under pressure from lawmakers to revise its agenda.}

\section{BY BOER DENG}

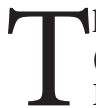

he US National Science Foundation (NSF) has had a tough couple of years. Republicans in the US Congress have put the agency under the microscope, questioning its decisions on individual grants and the purpose of entire fields of study. The agency was without a permanent director for a year, and it is now planning an expensive, and controversial, move to new headquarters.

As she prepares to mark one year at the agency's helm, astrophysicist France Córdova is carefully navigating these challenges. "I used to be a mountaineer," she says. "It's all about looking at every move and how you can best do it so that you don't take a fall." But many researchers worry that Congress has begun to interfere with the scientific process. As mistrust grows, the NSF is caught between the scientists it serves and the lawmakers it answers to.

Córdova has moved aggressively to repair relations with Congress. Aides to lawmakers who participated in a December trip to NSF facilities in Antarctica say that the journey was successful. And to address concerns about transparency, the agency has instituted guidelines that should make its grant summaries easier to understand.

But such efforts seem to have had little influence on an investigation of the NSF's funding decisions by Representative Lamar Smith (Republican, Texas), chairman of the House Committee on Science, Space, and Technology. Since he took the job two years ago, Smith has sought to root out what he sees as wasteful spending by the US\$7-billion NSF. He has introduced legislation that would require the agency to certify that every grant it awards is in the "national interest", and he has repeatedly sought, and been given, confidential information about individual NSF grants - albeit in redacted form. On at least four occasions, staff from the science committee travelled to the NSF's headquarters in Arlington, Virginia, to review such documents, most recently on 28 January.

"There is a sense of exhaustion among researchers as this has continued," says Meghan McCabe, a legislative-affairs analyst at the Federation of American Societies for Experimental Biology in Bethesda, Maryland.

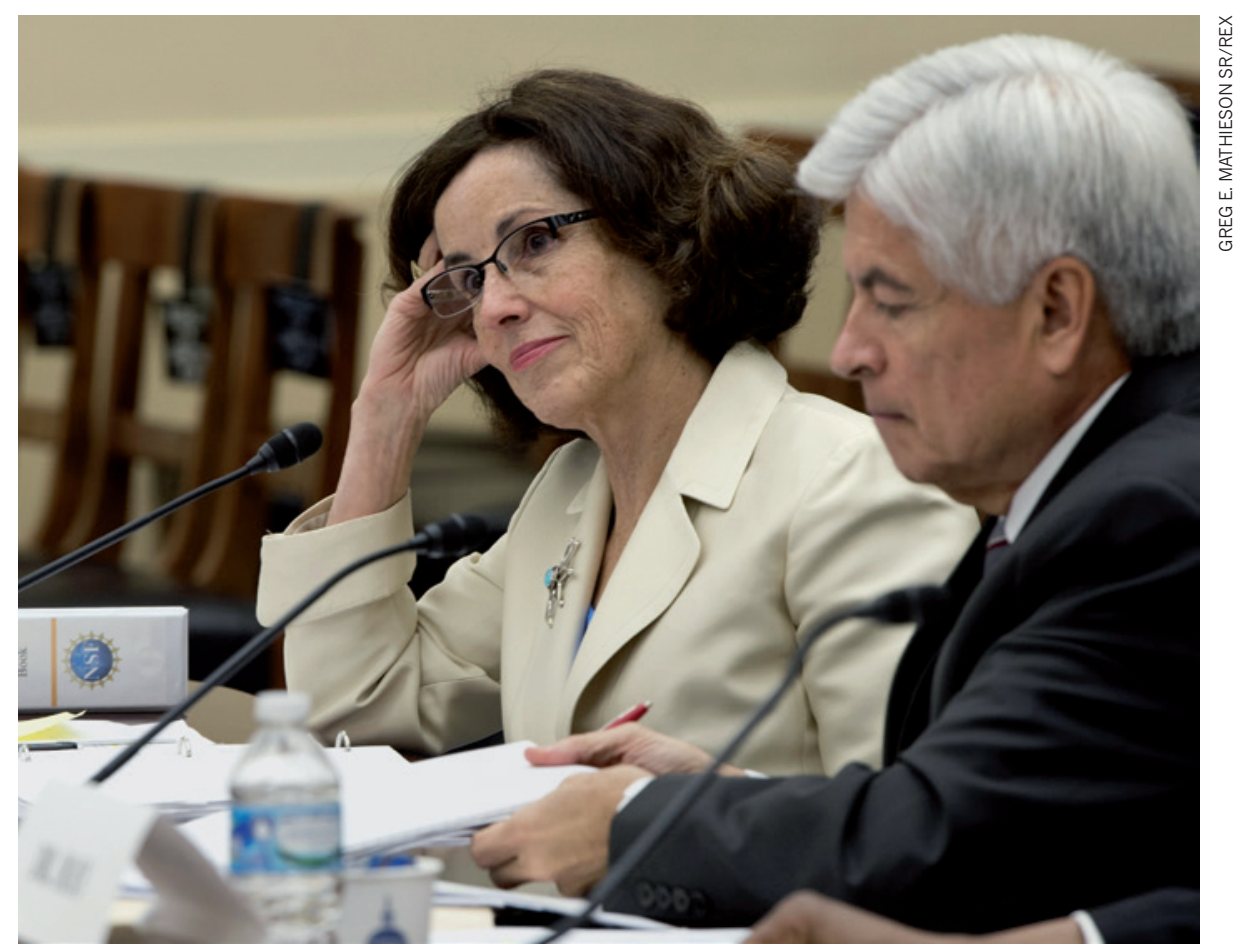

National Science Foundation head France Córdova (left) is trying to improve lawmakers' view of the agency.

An NSF programme director who asked not to be named is more direct: "Having them in our building questioning our work like that felt like an attack."

But Córdova argues that the political landscape has changed and the NSF must adapt. "Congress absolutely has the right to request whatever materials for oversight they want," she says. "Just because we're not used to it doesn't mean it's a violation." At a House subcommittee hearing in February, Córdova told lawmakers that she supports Smith's proposal to require that NSF grants support the national interest. (The NSF already judges grant applications on their potential "broader impacts" as well as on scientific merit; in December, it began asking applicants to articulate how their projects serve the national interest, as defined by the agency's mission statement.)

Among scientists, however, there is anxiety that Córdova has been too conciliatory towards critics in Congress. "Once you start to compromise, you're just inviting harassment," says Lloyd Etheredge, a social scientist at the Policy Sciences Center in Bethesda.
Some argue that the concessions to Congress will compromise the agency's peer-review process. "If the NSF is funding a grant, it should by definition be in the national interest," says John Bruer, president emeritus of the James S. McDonnell Foundation in St Louis, Missouri, who in 2011 led an NSF task force on grant criteria. "When you add stuff about the national interest, you are potentially inviting criteria apart from judging the best science."

\section{MANY PRIORITIES}

The agency's ongoing struggle with Congress has left Córdova with less time to deal with internal challenges, such as employees who are disgruntled by a 2013 decision to move NSF's headquarters from a suburb close to Washington DC to a site that is farther away and has smaller facilities for some staff. In October, a federal government arbitrator sided with an NSF employee union and ordered the agency to revise its design to accommodate large, individual workspaces in the new headquarters. Córdova has sought to address unrest about the move through a series of meetings and working 
groups, but rumours persist that many senior employees will opt to retire rather than relocate.

That would be a significant blow to an agency that is already stretched. The NSF's budget has grown slowly but steadily in recent years, reaching $\$ 7.3$ billion in fiscal year 2015 . But even though the number of grant proposals submitted to the agency has risen by $65 \%$ over the past 15 years, the NSF has seen only a $20 \%$ increase in the number of full-time employees.
The resulting increase in workload has affected staff morale. A 2014 survey by the US Office of Personnel Management found that only $45 \%$ of NSF employees felt that the agency's leadership generated "high levels of motivation and commitment in the workforce", compared with $53 \%$ in 2010 . And just over one-third of workers were negative about the opportunities available for getting a better job at the agency.
As Córdova enters the second year of her six-year term, the challenges ahead are clear.

Eugene Skolnikoff, a political scientist at the Massachusetts Institute of Technology in Cambridge, says that winning and maintaining the trust of the scientific community gives an NSF director clear authority to negotiate with Congress. "The best NSF directors," he says, "have been the ones who really got the staff and the scientists behind their vision."

\section{DNA clock proves tough to set}

\section{Geneticists meet to work out why the rate of mutation in the human genome is hard to pin down.}

\section{BY EWEN CALLAWAY}

$\mathrm{M}$ athematicians keep refining $\pi$ even though they know it to more than 12 trillion digits; physicists beat themselves up because they cannot pin down the gravitational constant beyond three significant figures. Geneticists, by contrast, are having trouble deciding between one measure of how fast human DNA mutates and another that is half that rate.

The rate is key to calibrating the 'molecular clock' that puts DNA-based dates on events in evolutionary history. So at an intimate meeting in Leipzig, Germany, on 25-27 February, a dozen speakers puzzled over why calculations of the rate at which sequence changes pop up in human DNA have been so much lower in recent years than previously. They also pondered why the rate seems to fluctuate over time. The meeting drew not only evolutionary geneticists, but also researchers with an interest in cancer and reproductive biology - fields in which mutations have a central role.

"Mutation is ultimately the source of all heritable diseases and all biological adaptations, so understanding the rate at which mutations evolve is a fundamental question," says Molly Przeworski, a population geneticist at Columbia University in New York City who attended the Human Mutation Rate Meeting.

Researchers tried to put a number on the human mutation rate even before they

knew that genetic information is encoded in DNA. In the 1930s, pioneering geneticist J. B. S. Haldane came up with a good estimate by measuring how the mutations responsible for haemophilia appeared in extended families. Later estimates of the mutation rate counted the differences between stretches of DNA and protein amino-acid sequences in humans and those in chimpanzees or other apes, and then divided the number of differences by the time that has elapsed since the species' most recent common ancestor appeared in the fossil record. These estimates were clouded by the patchiness of the fossil record, but researchers eventually settled on a consensus: each DNA

"The fact that
the clock is so
uncertain is very
problematic
for us."

letter, on average, mutates once every billion years. That is a "suspiciously round number", molecular anthropologist Linda Vigilant of the Max Planck Institute for Evolutionary Anthropology in Leipzig told Nature in 2012 (see Nature 489, 343-344; 2012).

In the past six years, more-direct measurements using 'next-generation' DNA sequencing have come up with quite different estimates. A number of studies have compared entire genomes of parents and their children and calculated a mutation rate that consistently comes to about half that of the last-commonancestor method.
A slower molecular clock worked well to harmonize genetic and archaeological estimates for dates of key events in human evolution, such as migrations out of Africa and around the rest of the world ${ }^{1}$. But calculations using the slow clock gave nonsensical results when extended further back in time - positing, for example, that the most recent common ancestor of apes and monkeys could have encountered dinosaurs. Reluctant to abandon the older numbers completely, many researchers have started hedging their bets in papers, presenting multiple dates for evolutionary events depending on whether mutation is assumed to be fast, slow or somewhere in between.

Last year, population geneticist David Reich of Harvard Medical School in Boston, Massachusetts, and his colleagues compared the genome of a 45,000-year-old human from Siberia with genomes of modern humans and came up with the lower mutation rate $^{2}$. Yet just before the Leipzig meeting, which Reich coorganized with Kay Prüfer of the Max Planck Institute for Evolutionary Anthropology, his team published a preprint article $\mathrm{e}^{3}$ that calculated an intermediate mutation rate by looking at differences between paired stretches of chromosomes in modern individuals (which, like two separate individuals' DNA, must ultimately trace back to a common ancestor). Reich is at a loss to explain the discrepancy. "The fact that the clock is so uncertain is very problematic for us," he says. "It means that the

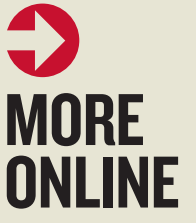

PICTURES OF THE MONTH

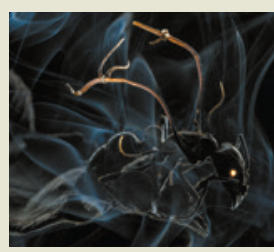

Zombie ants, mummified seals and a gorilla punch go.nature.com/ $\mathrm{mn} 4 \mathrm{fsx}$

\section{MORE NEWS}

- No link between psychedelics and psychosis go.nature.com/cwramz - How Ebola survivors mustered an immune defence go.nature.com/6d3upn - Complex societies evolved without belief in all-powerful deity go.nature.com/kumjxo
STORY OF THE WEEK

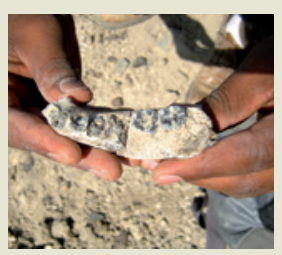

Ethiopian jawbone may mark dawn of humankind go.nature.com/ icyibm 